\title{
Reaction to Stress and How to Cope with it: A Case at Anadolu University
}

\author{
Rüçhan Gökdağ \\ Anadolu University, Faculty of Communicational Sciences \\ rgokdag@anadolu.edu.tr
}

\begin{abstract}
Individuals, who spend an important part of their lives on education, are inevitably exposed to stress when they begin undertaking more responsibilities and getting anxious about their future lives after ending their education lives. In other words, one can easily observe the symptoms of stress in individuals' personal lives as soon as their school lives come to an end. In this respect, in order to obtain information about students' thoughts regarding stress and about the mechanisms they use to cope with stress, the present study was conducted with students attending Anadolu University. In the study, a questionnaire was applied to a total of 600 students from such faculties of Anadolu University Faculty of Communication Sciences, Literature Faculty, Education Faculty, School of Physical Education and Sports, and Faculty of Pharmacy in the academic year of 2016-2017. Among all these students, 587 of them responded to the questionnaire. In the study, the purpose was to determine the students' views about the mechanisms they use or avoid using under stress, about their coping with stress and about the causes of their stress. In line with their responses, the findings were examined under related dimensions, and the relationship between the most frequent defense mechanisms and the response categories was tested using Pearson Correlation. In addition, Cochran $\mathrm{Q}$ test was applied whether there was a significant relationship between the most frequent defense mechanisms of reaction formation and spoilt reaction, the rationalist approach and the fanciful approach. Consequently, there were significant relationships between the response categories, and significant relationships were found between certain defense mechanisms.
\end{abstract}

Keywords: Stress, Stress Mechanisms, Coping with Stress, Causes of Stress

\section{Introduction}

In order to go on their lives and to continue their lineage, all living beings are supposed to adopt themselves to the environment where they were born and brought up. However, people have been involved in the process of this adaptation not just biologically but mentally as well. People's mental adaptation occurred mostly to preserve their personality integrity rather than to survive when they started controlling the nature and got out of the food chain. Human personality - with all its contradictory aspects - is regarded as a whole, and it involves the all the dilemmas of correct-wrong, good-bad and beautiful-ugly. Accepting human as a whole means accepting all these dilemmas. The reason is that what helps people develop their own personalities is the fight between these dilemmas, the consequent feelings of guilt, coping with these feelings, the effort to preserve their integrity, and the method they select.

People evaluate the world from their own perspectives of life and develop attitudes towards the problems accordingly. The basic reasons for developing such attitudes include not only the damage to individuals' inner world but also the desire to lead a life in harmony. According to Freud, all human behaviors are for adaptation. None of them 
are random-based; in contrast, any behavior of humans reflects different aspects of the effort to continue their lives (Freud, 1983 cited in Gençtan, 1996: 72). As mentioned by a well-known philosopher, Judith Butler (2009: 12), "Though life itself requires survival in life, leading a good life is a lot more than this."

Throughout their lives, people develop various defense mechanisms against the stressful conditions they meet. Some people try to preserve their personality and mental health via imagination, some via rationalization and some other people do so via humor. Since situations like getting stuck in cases of certain phenomena and failing to maintain the routine will hinder individual achievements, it is necessary to get rid of such situations immediately. There are countless causes of stress, one of important diseases of our era. The stress that individuals are exposed to occur with such reactions as anger, disappointment, tension and bewilderment. It is impossible for people to avoid stress, but they can control and manage it with the help of coping techniques. In addition, it is pointed out that a reasonable level of stress colors up human life and contributes to people's motivation, attention and sensitivity (Durna, 2006: 320).

Although the time and degree of the stress individuals are exposed to depend on the individuals themselves, university life has a special place in terms of the variety of sources of stress. University life is a period in which individuals experience various developmental problems. Young people at the age attending a university try to find their own identities, deal with social problems, adopt national and international values, and go through the processes of adaptation and maturation (Çuhadaroğlu, 1989). University students' roles and attitudes start changing based on their environment at university as well as on their development levels. The changes in the conditions of individuals' education lives when they start their university education include living away from family, being successful at university, finishing university education, feeling concerned about finding a job and having a good career, and these are all sources of stress for individuals. Besides all these factors, the thought of feeling oneself responsible for the society is another source of stress.

The cases which the researcher herself observed at the university where she is employed caused her to investigate which defense mechanisms are used by university students to cope with stress. In this respect, the research problem was to reveal to what extent and which defense mechanisms university students use when they are in stressful situations. In addition, the students were asked to state their views about stress as well.

\subsection{Research Purpose}

The purpose of the present study was not only to reveal whether students are exposed to stress and to what extent and which defense mechanisms they use to cope with stress but also to determine their views about stress.

The study was carried out with students such faculties of Anadolu University Faculty of Communication Sciences, Literature Faculty, Education Faculty, Faculty of Pharmacy and School of Physical Education and Sports in the academic year of 2016-2017.

\section{Research Method}

The study was conducted using the case study method to investigate the stress the university students were exposed to and the defense mechanisms they used to cope with stress as well as to determine their views about stress.

The study was carried out with face-to-face university students from different faculties of Anadolu University in the academic year of 2016-2017. The study group included a total of 600 students from the faculties. 
In the study, the research data were collected in relation to the extent of the university students' use of various defense mechanisms, their coping with stress, and their views about stress. As the data collection tool, a questionnaire prepared by the researcher was used and applied to 600 students participating in the study. Of all these participants, the responses of 587 students were taken into account for analysis.

\section{Data Analysis and Findings}

The participants' responses to the questions were categorized into dimensions and evaluated separately. The relationship between the most frequent defense mechanisms and the dimensions was examined using Pearson Correlation. In addition, Cochran $\mathrm{Q}$ test was applied to see whether there was a significant relationship between the most frequent defense mechanisms.

The responses of the 587 students were first categorized into dimensions by an expert. As there were responses belonging to more than one dimension, a column was formed for each dimension in the data table. The responses which belonged to the category under the related heading were marked as "yes", and those which did not were marked as "No".

The response categories and the dimensions formed as described above can be seen in Table 1.

Table 1.Response Categories and Dimensions

\begin{tabular}{|c|c|}
\hline Dimension & Response Categories \\
\hline $\begin{array}{l}\text { Most Frequent Defense } \\
\text { Mechanisms }\end{array}$ & $\begin{array}{ll}\text { - } & \text { Rationalist Approach } \\
\text { - } & \text { Repressive Approach } \\
\text { - } & \text { Fanciful Approach } \\
\text { - } & \text { Reaction formation and Spoilt Reaction } \\
\text { - } & \text { Humorous Approach } \\
\text { - } & \text { Solving a Problem } \\
\text { - } & \text { Compatibility }\end{array}$ \\
\hline Frequent Defense Mechanisms & $\begin{array}{ll}\text { - } & \text { Rationalist Approach } \\
\text { - } & \text { Repressive Approach } \\
\text { - } & \text { Withdrawal } \\
\text { - } & \text { Fanciful Approach } \\
\text { - } & \text { Reaction Formation } \\
\text { - } & \text { Solving a Problem } \\
\text { - } & \text { Compatibility }\end{array}$ \\
\hline $\begin{array}{c}\text { Less Frequent Defense } \\
\text { Mechanisms }\end{array}$ & $\begin{array}{ll}- & \text { Rationalist Approach } \\
\text { - } & \text { Repressive Approach } \\
\text { - } & \text { Prevention (Frustration) } \\
\text { - } & \text { Taking action } \\
\text { - } & \text { Fanciful Approach } \\
\text { - } & \text { Reaction Formation } \\
\text { - } & \text { Compatibility } \\
\end{array}$ \\
\hline $\begin{array}{c}\text { Defense Mechanisms Never } \\
\text { Used }\end{array}$ & $\begin{array}{ll}- & \text { Positive } \\
- & \text { Negative } \\
- & \text { Both positive and negative }\end{array}$ \\
\hline Coping with Stress & $\begin{array}{ll}\text { - } & \text { Repressive Approach } \\
\text { - } & \text { Hobbies and Activities } \\
\text { - } & \text { Reaction Formation } \\
\text { - } & \text { Moral Expectations } \\
\text { - } & \text { Affirmation } \\
\text { - } & \text { Dealing with the Problem }\end{array}$ \\
\hline
\end{tabular}




\begin{tabular}{|l|l|}
\hline \multirow{4}{*}{ Causes of Stress } & - Pressure \\
& - Environmental Problems and Changes \\
& - Obstacle \\
& - Pnxiety about future, Apprehension, \\
& - Daily Problems \\
- & Career, Job and Financial Problems \\
- & Concerns about health \\
& - Close and Private Relationship Problems \\
\hline
\end{tabular}

\subsection{Findings Regarding the Dimensions}

Table 2 presents the responses regarding the most frequent defense mechanisms.

Table 2. Most Frequent Defense Mechanisms

\begin{tabular}{|l|c|c|c|c|}
\hline \multicolumn{1}{|c|}{ Response } & No & Yes & No \% & Yes \% \\
\hline Repressive Approach & 356 & 231 & 60,65 & 39,36 \\
\hline Rationalist Approach & 483 & 104 & 82,29 & 17,72 \\
\hline Fanciful Approach & 490 & 97 & 83,48 & 16,53 \\
\hline Reaction Formation and Spoilt Reaction & 498 & 89 & 84,84 & 15,17 \\
\hline Compatibility & 522 & 65 & 88,93 & 11,08 \\
\hline Solving a Problem & 561 & 26 & 95,58 & 4,43 \\
\hline Humorous Approach & 573 & 14 & 97,62 & 2,39 \\
\hline
\end{tabular}

Among the most frequent defense mechanisms, the "Repressive Approach" received the highest response rate of "yes" $(39,36 \%)$, which was followed by the "Rationalist Approach" and the "Fanciful Approach", whilethe two lowest rates of "yes" belonged to the "Humorous Approach" $(2,39)$ and to the "Solving a Problem" $(4,43)$.

Table 3 presents the responses in relation to the frequent defense mechanisms.

Table 3. Frequent Defense Mechanisms

\begin{tabular}{|l|c|c|c|c|}
\hline \multicolumn{1}{|c|}{ Response } & No & Yes & No \% & Yes \% \\
\hline Repressive Approach & 492 & 95 & 83,82 & 16,19 \\
\hline Reaction Formation & 495 & 92 & 84,83 & 15,68 \\
\hline Rationalist Approach & 525 & 62 & 89,44 & 10,57 \\
\hline Compatibility & 528 & 59 & 89,95 & 10,06 \\
\hline Dealing with the Problem & 551 & 36 & 93,87 & 6,14 \\
\hline Withdrawal & 558 & 29 & 95,06 & 4,95 \\
\hline Fanciful Approach & 559 & 28 & 95,23 & 4,78 \\
\hline
\end{tabular}

Among the frequent defense mechanisms, repressive approach and reaction formation were responded to as 'yes' with the ratios of $16,19 \%$ and $15,68 \%$, respectively. On the other hand, withdrawal and fanciful approach were ranked as the last two frequent defense mechanisms receiving the response of 'yes' with the ratios of $4,95 \%$ and $4,78 \%$, respectively.

Table 4 presents the less frequent defense mechanism.

Table 4. Less Frequent Defense Mechanisms

\begin{tabular}{|l|c|c|c|c|}
\hline \multicolumn{1}{|c|}{ Response } & No & Yes & No \% & Yes \% \\
\hline Repressive Approach & 494 & 93 & 84,16 & 15,85 \\
\hline Reaction Formation & 500 & 87 & 85,18 & 14,83 \\
\hline Compatibility & 529 & 58 & 90,12 & 9,89 \\
\hline Rationalist Approach & 538 & 49 & 91,66 & 8,35 \\
\hline
\end{tabular}




\begin{tabular}{|l|c|c|c|c|}
\hline Fanciful Approach & 543 & 44 & 92,51 & 7,50 \\
\hline Taking Action & 562 & 25 & 95,75 & 4,26 \\
\hline Prevention (Frustration) & 572 & 15 & 97,45 & 2,56 \\
\hline
\end{tabular}

Among the defense mechanisms which were not used at all, repressive approach and reaction formation received the highest response of 'yes' with the ratios of $15,85 \%$ and $14,83 \%$, respectively. The lowest response ratio of 'yes' belonged to prevention (frustration) with $2,56 \%$.

Table 5 presents the defense mechanisms which were never used.

Table 5. Defense Mechanisms Which Were Never Used

\begin{tabular}{|l|c|c|c|c|}
\hline \multicolumn{1}{|c|}{ Response } & No & Yes & No \% & Yes \% \\
\hline Positive & 405 & 182 & 68,99 & 31,01 \\
\hline Negative & 420 & 167 & 71,56 & 28,45 \\
\hline Both Positive and Negative & 565 & 22 & 96,26 & 3,75 \\
\hline
\end{tabular}

Among the defense mechanisms which were never used, negative received the response of 'yes' with a ratio of $31,01 \%$, while positive received the response of 'yes' with a ratio of $28,45 \%$. In addition, both positive and negative were responded to as 'yes' with a ratio of $3,75 \%$.

Table 6 presents the responses regarding the methods of coping with stress.

Table 6. Methods of Coping with Stress

\begin{tabular}{|l|c|c|c|c|}
\hline \multicolumn{1}{|c|}{ Response } & No & Yes & No \% & Yes \% \\
\hline Dealing with the Problem & 498 & 89 & 84,84 & 15,17 \\
\hline Repressive Approach & 526 & 61 & 89,61 & 10,40 \\
\hline Hobbies and Activities & 537 & 50 & 91,49 & 8,52 \\
\hline Affirmation & 573 & 14 & 97,62 & 2,39 \\
\hline Moral Expectations & 577 & 10 & 98,30 & 1,71 \\
\hline Reaction formation & 579 & 8 & 98,64 & 1,37 \\
\hline
\end{tabular}

Among the methods of coping with stress, dealing with the problem and repressive approach received the response of 'yes' with the ratios of $15,17 \%$ and $10,40 \%$, respectively. In addition, affirmation, moral expectations and reaction formation received the response of 'yes' with the ratios of $2,39 \%, 1,17 \%$ and $1,37 \%$, respectively.

The responses regarding the causes of stress can be seen in Table 7.

Table 7. Causes of Stress

\begin{tabular}{|l|c|c|c|c|}
\hline \multicolumn{1}{|c|}{ Response } & No & Yes & No \% & Yes \% \\
\hline Close and Private Relationship Problems & 321 & 266 & 54,69 & 45,32 \\
\hline Career, Job and Financial Problems & 324 & 263 & 55,20 & 44,81 \\
\hline Environmental Problems and Changes & 468 & 119 & 79,73 & 20,28 \\
\hline Concerns about Health & 481 & 106 & 81,95 & 18,06 \\
\hline $\begin{array}{l}\text { Anxiety about Future, Apprehension, } \\
\text { Pessimism and Fear }\end{array}$ & 494 & 93 & 84,16 & 15,85 \\
\hline Daily Problems & 551 & 36 & 93,87 & 6,14 \\
\hline Obstacle & 574 & 13 & 97,79 & 2,22 \\
\hline Pressure & 575 & 12 & 97,96 & 2,05 \\
\hline
\end{tabular}

Among the causes of stress, close and private relationship problems and career, job and financial problems were responded to as 'yes' with the ratios of $45,32 \%$ and $44,81 \%$, 
respectively. The two lowest ratios of the response of 'yes' belonged to obstacle and pressure with $2,22 \%$ and $2,05 \%$, respectively.

\subsection{Findings Regarding Pearson Correlation}

The most frequent defense mechanisms were divided into seven dimensions. In order to examine the relationship between the response categories of the dimensions, Pearson Correlation was used, and the Significance value (2-Tailed) was interpreted based on the significance levels of $p<0,05$ and $p<0,01$.

Table 8 presents Pearson Correlation regarding the response categories of the most frequent defense mechanisms.

Table 8. Pearson Correlation Analysis Regarding the Response Categories of the Most Frequent Defense Mechanisms

\section{Correlations}

ecksm. ecksm. ecksm. ecksm. ecksm. ecksm.

\begin{tabular}{|c|c|c|c|c|c|c|c|c|}
\hline & & 1 & 2 & 3 & 4 & 5 & 6 & ecksm.7 \\
\hline \multirow[t]{3}{*}{$\begin{array}{l}\text { ecksm. } \\
1\end{array}$} & $\begin{array}{l}\text { Pearson } \\
\text { Correlatio } \\
n\end{array}$ & 1 & $-0,036$ & $130^{* *}$ & 0,003 & 0,044 & $-0,057$ & $-0,007$ \\
\hline & $\begin{array}{l}\text { Sig. (2- } \\
\text { tailed) }\end{array}$ & & 0,386 & 0,002 & 0,944 & 0,282 & 0,171 & 0,859 \\
\hline & $\mathrm{N}$ & 587 & 587 & 587 & 587 & 587 & 587 & 587 \\
\hline \multirow[t]{3}{*}{$\begin{array}{l}\text { ecksm. } \\
2\end{array}$} & $\begin{array}{l}\text { Pearson } \\
\text { Correlatio } \\
n\end{array}$ & $-0,036$ & 1 & 0,036 & 0,078 & $125^{* *}$ & 0,013 & 0,049 \\
\hline & $\begin{array}{l}\text { Sig. (2- } \\
\text { tailed) }\end{array}$ & 0,386 & & 0,385 & 0,060 & 0,002 & 0,753 & 0,235 \\
\hline & $\mathrm{N}$ & 587 & 587 & 587 & 587 & 587 & 587 & 587 \\
\hline \multirow[t]{3}{*}{$\begin{array}{l}\text { ecksm. } \\
3\end{array}$} & $\begin{array}{l}\text { Pearson } \\
\text { Correlatio } \\
n\end{array}$ & $130^{* *}$ & 0,036 & 1 & $106^{*}$ & 0,081 & $105^{*}$ &, $121^{* *}$ \\
\hline & $\begin{array}{l}\text { Sig. (2- } \\
\text { tailed) }\end{array}$ & 0,002 & 0,385 & & 0,010 & 0,050 & 0,011 & 0,003 \\
\hline & $\mathrm{N}$ & 587 & 587 & 587 & 587 & 587 & 587 & 587 \\
\hline \multirow[t]{3}{*}{$\begin{array}{l}\text { ecksm. } \\
4\end{array}$} & $\begin{array}{l}\text { Pearson } \\
\text { Correlatio } \\
\mathrm{n}\end{array}$ & 0,003 & 0,078 & $106^{*}$ & 1 &, $152^{* *}$ & 0,024 & ,093* \\
\hline & $\begin{array}{l}\text { Sig. (2- } \\
\text { tailed) }\end{array}$ & 0,944 & 0,060 & 0,010 & & 0,000 & 0,555 & 0,024 \\
\hline & $\mathrm{N}$ & 587 & 587 & 587 & 587 & 587 & 587 & 587 \\
\hline \multirow[t]{3}{*}{$\begin{array}{l}\text { ecksm. } \\
5\end{array}$} & $\begin{array}{l}\text { Pearson } \\
\text { Correlatio } \\
n\end{array}$ & 0,044 & $125^{* *}$ & 0,081 & $152^{* *}$ & 1 & $129^{* *}$ &, $087^{*}$ \\
\hline & $\begin{array}{l}\text { Sig. (2- } \\
\text { tailed) }\end{array}$ & 0,282 & 0,002 & 0,050 & 0,000 & & 0,002 & 0,035 \\
\hline & $\mathrm{N}$ & 587 & 587 & 587 & 587 & 587 & 587 & 587 \\
\hline \multirow[t]{3}{*}{$\begin{array}{l}\text { ecksm. } \\
6\end{array}$} & $\begin{array}{l}\text { Pearson } \\
\text { Correlatio } \\
\mathrm{n}\end{array}$ & $-0,057$ & 0,013 & $105^{*}$ & 0,024 & $129^{* *}$ & 1 &, $082^{*}$ \\
\hline & $\begin{array}{l}\text { Sig. (2- } \\
\text { tailed) }\end{array}$ & 0,171 & 0,753 & 0,011 & 0,555 & 0,002 & & 0,046 \\
\hline & $\mathrm{N}$ & 587 & 587 & 587 & 587 & 587 & 587 & 587 \\
\hline
\end{tabular}




\begin{tabular}{llr|r|rrrrr}
\hline $\begin{array}{l}\text { ecksm. } \\
7\end{array}$ & $\begin{array}{l}\text { Pearson } \\
\text { Correlatio } \\
\mathrm{n}\end{array}$ & $-0,007$ & 0,049 &, $121^{* *}$ &, $093^{*}$ &, $087^{*}$ &, $082^{*}$ & 1 \\
\hline $\begin{array}{l}\text { Sig. }(2- \\
\text { tailed) }\end{array}$ & 0,859 & 0,235 & 0,003 & 0,024 & 0,035 & 0,046 & \\
\hline $\mathrm{N}$ & 587 & 587 & 587 & 587 & 587 & 587 & 587 \\
\hline
\end{tabular}

**. Correlation is significant at the 0.01 level (2-tailed).

*. Correlation is significant at the 0.05 level (2-tailed).

There was a positive relationship between rationalist approach and fanciful approach with a ratio of $13 \%(p<0,01)$.

There was a positive relationship between repressive approach and humorous approach with a ratio of $12,5 \%(p<0,01)$.

There was a positive relationship between fanciful approach and reaction formation with a ratio of $10,5 \%(p<0,05)$. There was a positive relationship between fanciful approach and solving the problem with a ratio of $10,5 \%(p<0,01)$. There was a positive relationship between fanciful approach and compatibility with a ratio of $12,1 \%$ ( $p<$ $0,01)$.

There was a positive relationship between reaction formation and spoilt reaction and humorous approach with a ratio of $15,2 \%(p<0,01)$. There was a positive relationship between reaction formation and spoilt reaction and compatibility with a ratio of $9,3 \%$ ( $p$ $<0,05)$.

There was a positive relationship between humorous approach and solving the problem with a ratio of $12,9 \%(p<0,01)$. There was a positive relationship between humorous approach and compatibility with a ratio of $8,7 \%(p<0,05)$.

There was a positive relationship between solving the problem and compatibility with a ratio of $4,6 \%(p<0,05)$.

\subsection{Findings Regarding Cochran $\mathbf{Q}$ Test}

An important purpose of the study was to reveal the relationship between the defense of mechanisms of rationalist approach, fanciful approach, and reaction response and spoilt reaction. In the statistical hypothesis put forward, whether the rationalist approach, fanciful approach, and reaction formation and spoilt reaction belonged to the same defense mechanism or to different defense mechanisms, was tested. As the participants' responses belonged to different response categories, non-parametric Cochran Q test was preferred for the comparison due to the structure of the responses given. In other words, the reason for using the non-parametric Cochran $\mathrm{Q}$ test was that the data were appropriate to normal distribution.

Table 9 presents the findings obtained via the Cochran Q Test. 
Table 9. Findings Regarding the Cochran Q Test

Related-Samples Cochran's Q Test

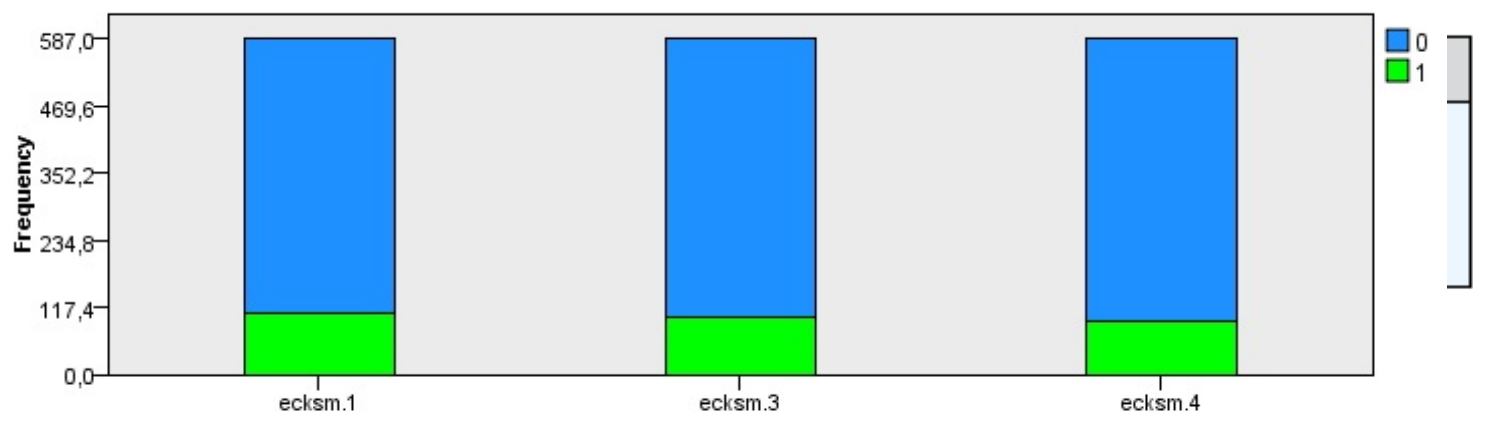

\begin{tabular}{|lr|}
\hline Total N & 587 \\
\hline Test Statistic & 1,516 \\
\hline Degrees of Freedom & 2 \\
\hline Asymptotic Sig. (2-sided test) &, 469 \\
\hline
\end{tabular}

1. Multiple comparisons are not performed because the overall test does not show significant differences across samples.

When the asymptotic significance value is subtracted from 0,05 in Cochran $Q$ testanalysis, it could be stated that the defense mechanisms of rationalist approach, fanciful approach, and reaction formation and spoilt reaction belong to the same response category. In the Cochran $Q$ test conducted, the asymptotic significance value was found to be 0,469 .

In this respect, as $p=0,469>0,05$, the hypothesis that the defense mechanisms of rationalist approach, fanciful approach, and reaction formation and spoilt reaction belong to the same response category is confirmed. There was a significant relationship between the defense mechanisms of rationalist approach, fanciful approach, and reaction formation and spoilt reaction.

\section{References}

Butler, J. (2009). Introduction: Precarious Life, Grievable Life, Frames of War: When is Life Grievable?, Londra: Verso

Çuhadaroğlu, F. (1989). Üniversite Gençliğind eKimlik Bocalamaları. Üniversite Gençliğinde Uyum Sorunları Sempozyumu Bilimsel Çalışmaları, Ankara: Bilkent Üniversitesi Psikolojik Danışma ve Araştırma Merkezi.

Durna, U. (2006). Üniversite Öğrencilerinin Stres Düzeylerinin Bazı Değişkenler Açısından İncelenmesi. Atatürk Üniversitesi İktisadi ve İdari Bilimler Dergisi, 20(1), 320-343.

Geçtan, E. (1996). Psikanaliz ve Sonrası, İstanbul: Remzi Kitabevi. 